\title{
A Legal Framework for Caring
}


Also available from Macmillan:

Akinsanya, J., Cox, G., Crouch, C. and Fletcher, L. (1994) The Roy Adaptation Model in Action. 


\section{A Legal Framework for Caring}

An introduction to law and ethics in health care

Lucy Fletcher and Paul Buka 
(C) Lucy Fletcher and Paul Buka 1999

All rights reserved. No reproduction, copy or transmission of this publication may be made without written permission.

No paragraph of this publication may be reproduced, copied or transmitted save with written permission or in accordance with the provisions of the Copyright, Designs and Patents Act 1988, or under the terms of any licence permitting limited copying issued by the Copyright Licensing Agency, 90 Tottenham Court Road, London W1P 9HE.

Any person who does any unauthorised act in relation to this publication may be liable to criminal prosecution and civil claims for damages.

The authors have asserted their right to be identified as the authors of this work in accordance with the Copyright, Designs and Patents Act 1988.

First published 1999 by

MACMILLAN PRESS LTD

Houndmills, Basingstoke, Hampshire RG21 6XS

and London

Companies and representatives

throughout the world

\section{ISBN 978-0-333-72778-2 ISBN 978-1-349-14755-7 (eBook)}

DOI 10.1007/978-1-349-14755-7

A catalogue record for this book is available from the British Library.

This book is printed on paper suitable for recycling and made from fully managed and sustained forest sources.

$\begin{array}{llllllllll}10 & 9 & 8 & 7 & 6 & 5 & 4 & 3 & 2 & 1\end{array}$

$\begin{array}{llllllllll}08 & 07 & 06 & 05 & 04 & 03 & 02 & 01 & 00 & 99\end{array}$

Editing and origination by Aardvark Editorial, Mendham, Suffolk 
For Brian and the Leonards

Carol, Sandy and Tinashe 


\section{Contents}

Acknowledgements $\quad \mathrm{x}$

Preface xi

Chapter 1 Law and morals in society - an overview 1

Introduction 1

Law and morality 4

$\begin{array}{ll}\text { The basis of UK law } & 7\end{array}$

Sources of Scottish law $\quad 7$

Sources of UK law - the broader aspect $\quad 8$

The European Community 9

$\begin{array}{ll}\text { Classification of law } & 10\end{array}$

$\begin{array}{ll}\text { The justice system } & 11\end{array}$

Legislation and formal rules governing the

$\begin{array}{ll}\text { caring relationship } & 13\end{array}$

Duty of care and clinical negligence $\quad 14$

Litigation, remedies and dispute resolution 17

$\begin{array}{ll}\text { Informed consent and information } & 19\end{array}$

A consensus of ethical issues 19

$\begin{array}{ll}\text { Conclusion } & 20\end{array}$

$\begin{array}{ll}\text { References and further reading } & 21\end{array}$

$\begin{array}{lll}\text { Chapter } 2 & \text { Caring within a framework } & 23\end{array}$

Introduction 23

$\begin{array}{ll}\text { The NHS } & 25\end{array}$

Resources $\quad 28$

Employment and industrial relations $\quad 31$

The multidisciplinary team and codes of conduct $\quad 35$

Record-keeping 38

Quality assurance in caring $\quad 39$

When it goes wrong - whistleblowing 40

$\begin{array}{ll}\text { Complaints } & 41\end{array}$

Research ethics 43

Conclusion $\quad 44$

References and further reading $\quad 45$ 


\section{Contents}

$\begin{array}{lll}\text { Chapter } 3 & \text { Working with the client } & 47\end{array}$

Introduction $\quad 47$

Confidentiality 48

Duty of care and accountability/responsibility 53

Negligence $\quad 55$

Vicarious liability $\quad 57$

Restraint and false imprisonment $\quad 58$

Assault and battery/consent to treatment $\quad 59$

Conscientious objection $\quad 61$

References and further reading $\quad 62$

$\begin{array}{lll}\text { Chapter } 4 & \text { Caring safely } & 64\end{array}$

Introduction $\quad 64$

The administration of drugs $\quad 65$

Health and safety at work $\quad 68$

Moving and handling $\quad 70$

RIDDOR and COSHH $\quad 72$

Food-handling $\quad 73$

Do not forget the administrators $\quad 76$

Conclusion $\quad 77$

References and further reading $\quad 78$

$\begin{array}{lll}\text { Chapter } 5 & \text { Care in the community } & 79\end{array}$

Background and the concept of care in the community 79

Acute care in the community and the

The care plan and funding issues $\quad 85$

Continuing care and the key players $\quad 88$

Disability and the physically disabled client 91

References and further reading 93

Chapter 6 The child - before and after birth 95

Introduction $\quad 95$

Biological origins $\quad 97$

Parental rights versus children's rights $\quad 97$

The beginning of life and assisted conception $\quad 98$

Research and surrogacy 101

Abortion 102

The child at home $\quad 102$

Child protection $\quad 104$

Children and the local authority 108

The child in hospital/informed consent 109 


\section{A Legal Framework for Caring}

The child at school and at work $\quad 111$

$\begin{array}{ll}\text { References and further reading } & 112\end{array}$

$\begin{array}{lll}\text { Chapter } 7 & \text { Mental handicap and mental health } & 114\end{array}$

Introduction 114

The Mental Health Acts 115

Consent to treatment 121

Guardianship and the Court of Protection 122

Abuse of the client $\quad 123$

Not in my backyard... 124

$\begin{array}{ll}\text { References and further reading } & 127\end{array}$

$\begin{array}{lll}\text { Chapter } 8 & \text { The dying client } & 129\end{array}$

Introduction 129

$\begin{array}{ll}\text { Euthanasia } & 129\end{array}$

Advance directives (living wills) 133

The multidisciplinary team in practice 135

Physician-assisted suicide and double effect 137

'Do not resuscitate' orders 138

After death 140

Transplantation $\quad 142$

Conclusion $\quad 143$

References and further reading $\quad 144$

$\begin{array}{lll}\text { Chapter } 9 \text { Caring for the elderly } & 146\end{array}$

Introduction 146

$\begin{array}{ll}\text { Background } & 147\end{array}$

Demographic changes - the effect on care of the elderly 149

Law of negligence and elderly clients $\quad 150$

Consent to treatment and the elderly client $\quad 152$

Elder abuse $\quad 155$

Measures for protecting property 158

The elderly in acute care and the discharge process 159

Conclusion: the future of care of the elderly 159

$\begin{array}{ll}\text { References and further reading } & 160\end{array}$

$\begin{array}{lll}\text { Chapter } 10 & \text { The last word } & 161\end{array}$

Introduction 161

Law and ethics - their relevance to caring $\quad 162$

Advocacy 163

Quality, audit and standards $\quad 164$

Consumerism and complaints $\quad 165$

$\begin{array}{ll}\text { The Ombudsman } & 167\end{array}$ 


\section{Contents}

Role of the providers of health care and the future of the NHS

The professions - where next?

References and further reading

Appendix Useful addresses

Index 


\section{Acknowledgements}

The authors of this book wish to thank all those who have so patiently helped us. We have been lucky to have had the support of our colleagues and friends, particularly Andrea, Ruth and Julia, who listened to us when it was going well and helped us through the sticky patches. We wish to acknowledge the valuable guidance that we have received from Richenda MiltonThompson.

A big thank you must go to the pre-registration students of all disciplines and to those studying for the NVQ who read drafts of the chapters, assessed them for their usefulness and also proofread the work. Our thanks must also go to the librarians who helped us to find obscure works and recommended others that might be of use.

We owe a debt of gratitude to ARD, Karen Law, Phillip Ojianko, and Susan and Claire Soper for their expertise and assistance with various aspects of the book. 


\section{Preface}

During the late 1980s and 90s, there were many changes in the legal framework of health care in the UK that have had an effect on the delivery of care. A radical reform of the National Health Service (NHS) has taken place over the past decade, allied to an increasing emphasis on care in the community by a multidisciplinary team working in collaboration for the benefit of its clients. A knowledge of the law and its basis is a vital part of the background and everyday practice of those who deliver health care to client groups.

Every effort has been made to ensure that the law quoted at the date of writing is correct. It is important to emphasise that this book is not intended to take the place of qualified legal advice or of that of trade union officials representing their members within the workplace. This book is designed to raise awareness of the relevant legislation and act as an introduction to the huge range of excellent texts that are available at a more advanced level. Each chapter is concluded by a section devoted to references and further reading relevant to the material contained within the chapter.

To simplify the learning process, case law has not been discussed as each case is judged on its individual merits and only a few keynote court decisions have been mentioned in the text. These decisions have come to form part of the everyday reference to the law made by health care professionals, and a fuller understanding of the process by which they have been determined will repay the more advanced student. Some of the care situations outlined are evolving within the law, the subject of euthanasia and the making of an advance directive (living will) being examples, so can only be discussed within the context of the law at the time of writing. Four chapters are devoted to general issues, with five discussing the law in relation to specific client groups. Addressing specific client groups has led to some duplication, for example in consent to treatment and duty of care, but this has been done in order to allow each chapter to stand alone within its client group. 


\section{A Legal Framework for Caring}

The increasing use of technology in the workplace and an acknowledgement of the need for good record-keeping has resulted in further legal implications for those who deliver care. The rights of patients and their carers have now been identified, and the recognition by clients and their relatives of their rights with regard to health care have raised expectations of the expected standard of care. The right to complain about care and an increasing tendency to go to litigation are features of contemporary health care delivery to which the health care worker's only answer rests in the maintenance of full, accurate records.

Caring is closely linked to the related areas of morals and ethics, many of which affect both client and carer. This book concentrates on 'practical ethics', requiring the reader to link practice situations, that is, practical ethics, with the law within a caring situation. This takes the form of thinking points within each chapter related to the area under discussion, designed to stimulate thought and facilitate the transfer of theory to clinical practice. This approach is linked to the problem- and inquirybased learning styles adopted within many educational courses at the present time. The thinking points have been extensively discussed by our students and colleagues in order to test their relevance, and their input was very valuable in the development of the book.

In order to ensure professional standards of practice and care, registered members of the multiprofessional caring team work within rules and codes of conduct developed by their professional bodies. The rules and codes form the yardstick for professional behaviour and standards both in the courts and for the professional bodies, and are briefly visited.

Changes, particularly in medical practice, have altered traditional patterns of accountability and responsibility, with consequent effects for all staff working with clients. The development of multidisciplinary care has resulted in a blurring of many of the former professional boundaries.

The importance of good communication and record-keeping is vital to permit effective co-ordination of the team members' work.

In this book, the terms 'health care worker' and 'health care professional' are used. 'Health care worker' relates to all those employed as paid carers, while 'health care professional' is used particularly in the context of the registered professional. The term 'client' has also been used unless the care setting is specifically within a hospital; this is to reflect the increasing emphasis on the care of all groups within the community. 


\section{Preface}

Lucy Fletcher is a senior lecturer in nursing with a particular interest in the legal and ethical issues of care delivery.

Paul Buka is an experienced nurse and ward manager. He has a law degree and is currently undertaking legal studies at Master's level. 